\title{
Foresighted Urban Planning
}

\section{Dalia Bardauskienė, Mindaugas Pakalnis}

Vilnius Gediminas Technical University, Lithuania

crossref $\mathrm{http}: / / \mathrm{dx}$.doi.org/10.5755/j01.erem.59.1.679

(received in September, 2011, accepted in March, 2012)

Lithuania is an urbanized country. The decisions of the soviet past have shaped a compact city character. After the Regaining of Independence in 1990, urbanization process was organized by the new territorial planning system. Democracy and market economy are rapidly changing the spatial pattern of Lithuania's urban structures. Based on the research done on urban trends and Master plans of the main metropolitan cities of the state, the contributors are trying to answer the question how much the current urban planning is foresighted in achieving sustainability goals and what actions are to be taken to avoid the spread of compact city structures, to stop ineffective use of land and other natural resources.

Authors have concluded that the current generation is responsible for a new spatial future of Lithuania. The future should be based on foresighted urban development i.e.on its vision and policy, on clear understanding about the existing situation supported by learned urban professionals

Key words: territorial planning, urban sprawl, urban trends, local master planning, urban professionals.

\section{Introduction}

The goal of this article is to revise the current urban planning process in main Lithuanian metropolitan cities and their neighboring municipalities in the light of current urban trends, sustainable development principles and to make recommendations for improvement of the territorial planning system. Since the urban development is a comprehensive object, the comprehensive methodology was chosen. Research was done and conclusions were made by using the EU urban and environmental policy documents and expert organization recommendations.

The current chaotic suburbanization in the global context is described as "urban sprawl ", which does not meet the principles of sustainable development (EU Council 2007, EU 2006, ISOCARP 2008, European Environment Agency 2007). Urban sprawl is also a matter of concern in Europe; nevertheless, only few countries notably in Northern Europe are coping with it well. The sprawl in cities of Eastern
Europe illustrates the development of "free for all" of 1990 and the impact of transition from socialist to free-market economy with its effect on local economies, social patterns and planning systems (Couch 2007). In Lithuania the growth of suburbanization took place not long ago, local specialists call it "urban chaos" or "spread of compact urban structures", etc. (Fourth Urban Forum 2010). The current spatial development order in Lithuania could be described as suburbanization and spread of compact urban structures.

The research done on the urban trends and Master plans of main metropolitan cities and their suburban municipalities has revealed that at a present decrease in population a great demand for land is rising. Suburbanization does not correlate with a demographic and economic situation; it raises the need for a new infrastructure, the price of public infrastructure and services. It has induced inhabitants' dependence on their own transport means, enhanced 
environment pollution and energy resources consumption.

The contributors have concluded that the Master plans of municipalities should be foresighted instruments for the long term sustainable development. In this situation it is useful to listen to famous urban thinker Jane Jacobs (1916 - 2006). In her last book "Dark Age Ahead" she has warned to lean on the professional and educational organizations based on content and thinking rather than licensing and mannerism. In Lithuania this goal can be achieved through the National Urban Forum. From the year 2007 the Forum is the strongest urban "think tank". The Forum suggests making territorial planning and management realistic, based on social and economical forecasts and coordinated urban \& rural development policy, supported by legal, financial measures. The enhancement of the role of the local government and citizens is an essential requisite. Those measures could make the urban planning foresighted (to manage and use effectively the inner territories of cities and valuable rural suburbs, to decrease the need for new public infrastructure and services; to stop the growth of energy consumption, use of own cars and environment pollution, to have aesthetic urban landscapes, (Fourth Urban Forum 2010).

\section{Current urban trends}

The new Lithuanian territorial planning system came into force in 1995 . That was the period of developing market and democracy, and today it has not been fully developed yet. This new urban planning and management system is rapidly changing the spatial patterns of Lithuania. Similarly to the case in many towns of Eastern and Central Europe, in Lithuania the level of urbanization is growing. About $70 \%$ of population live in settlements, but the total number of inhabitants is shrinking. If the Euro stat predictions come true, till the year 2060 the population in Lithuania will reach its postwar level, i.e. 2.5 million (Fig. 1). The present demographic situation is like that, which was in the year 1945, the trends of the past being compensated by the immigration from the Soviet Union. The current immigration policy is under the development.

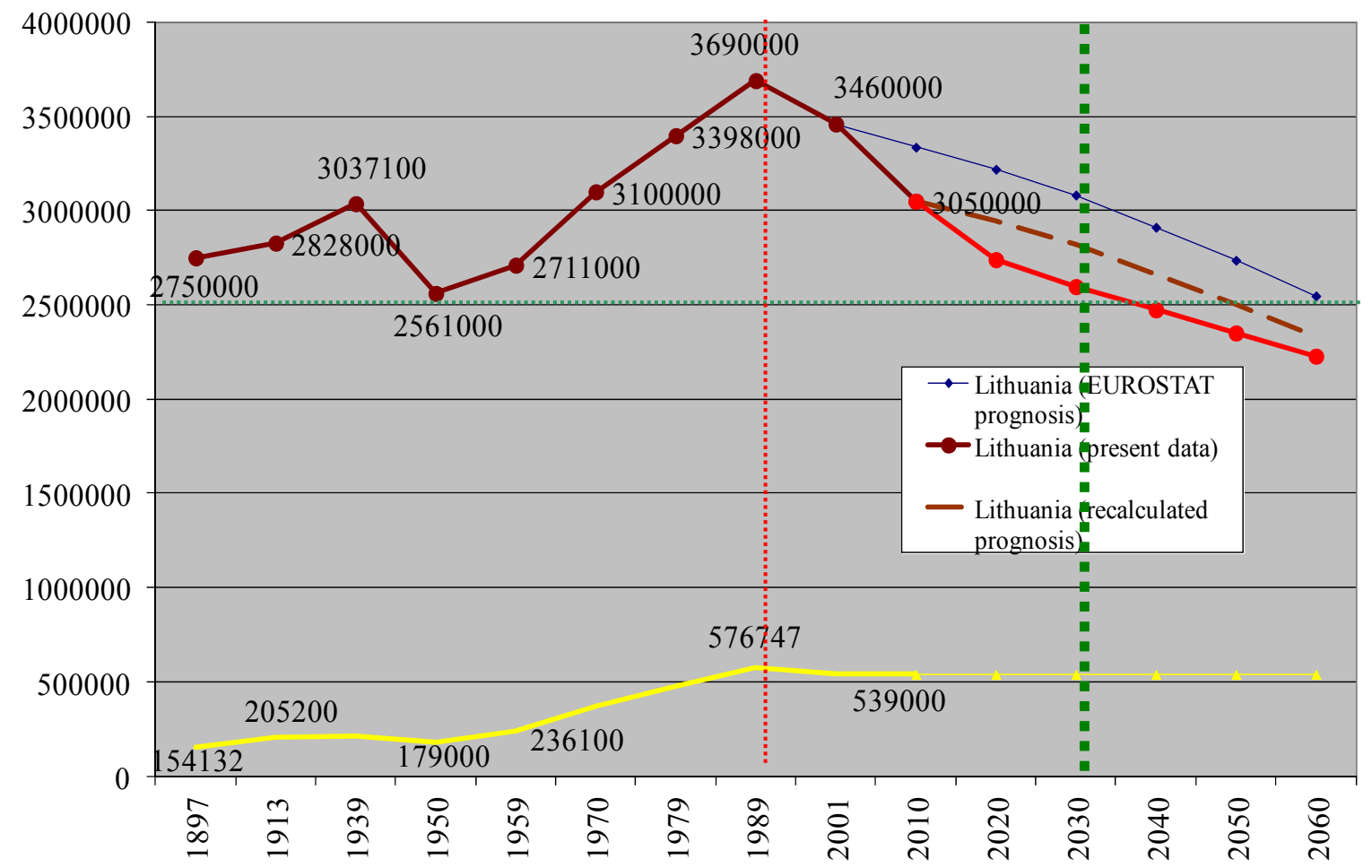

Fig.1. Demographic trends in Lithuania (source: Euro stat 2009)

The cities in Lithuania are shrinking, only one of the biggest cities - Vilnius holds the unchangeable number of inhabitants. Remaining cities show decreasing trends (Figure 2). For example, in 20012009 in Kaunas a decrease was $17 \%$, it is about 67 400 citizens, hence the number of the suburb inhabitants had been increasing. Migration of citizens from the cities to the suburbs is induced by the open market and "ad hoc" territory planning.

The territorial planning helps "pump up vital forces" from cities and towns, to occupy suburbs with new villages and to raise up the infrastructure needs, public services costs, and to pollute the environment. Predictions show that the number of elderly people of retiring age has greatly grown up (dependence on the factor will increase three times) and the possibility to use public funds for infrastructure development will be continuously decreasing. Presumption that cities will be able to hold citizens when suburbs and their infrastructure grow is unsophisticated. 


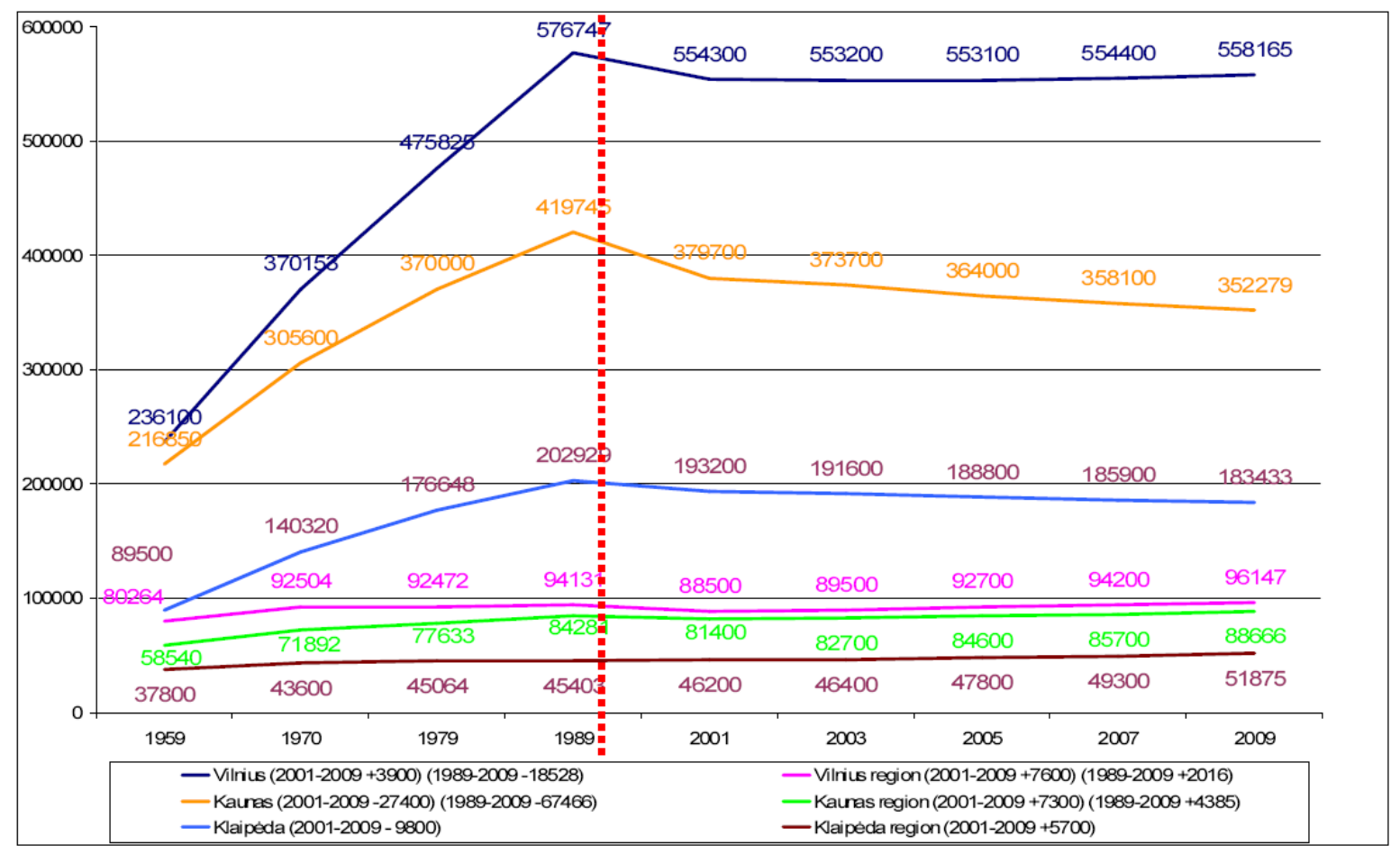

Fig. 2. Migration of citizens from the cities to the suburbs in 2001- 2009 (source: Lithuanian Statistical office 2009)
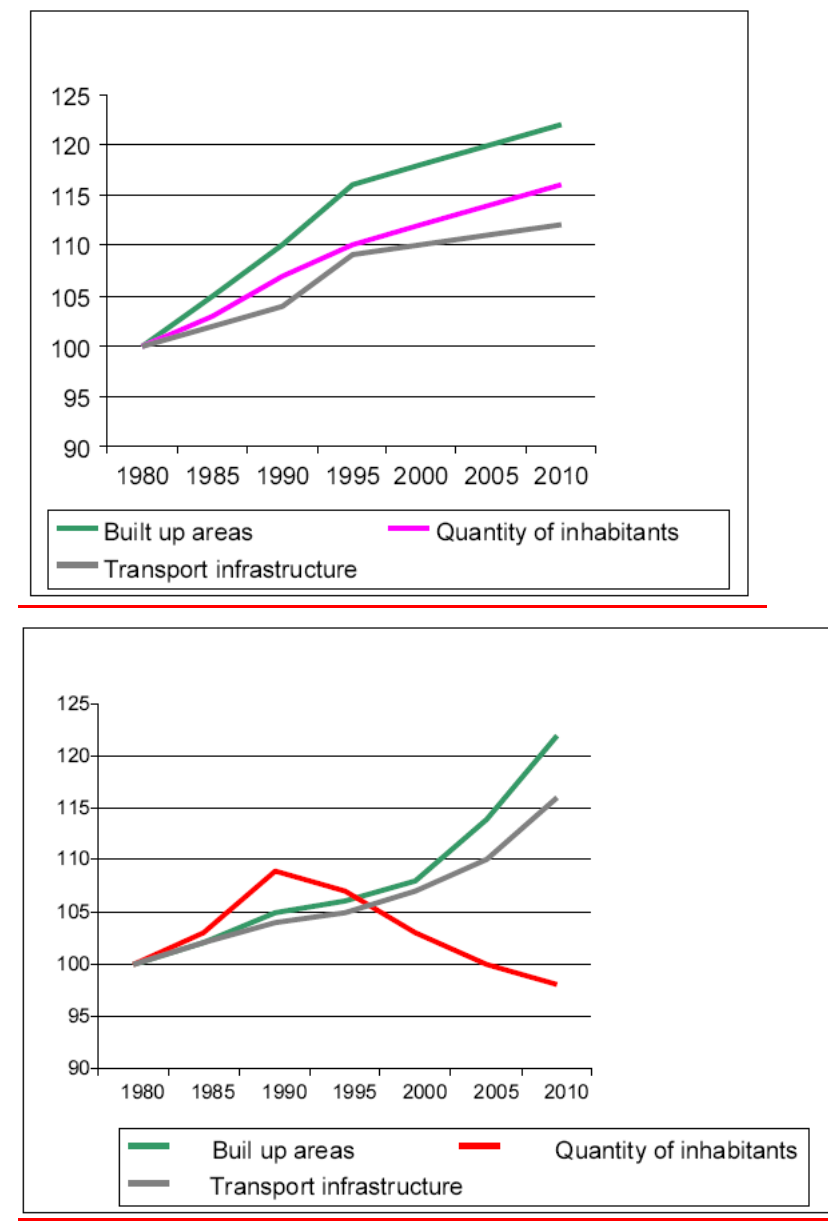

Fig. 3. Trends of the population, build-up areas and traffic infrastructure growth in the EU (Left Figure) and in Lithuania (sources: EEA report 2009; on the left side the results of the study carried out by the authors 2010)
The spread of urban structures to the suburban areas bears consequences on social-and-economic environment. Figure 3 provides the comparison of build-up territories, traffic infrastructure, and demographical trends of Lithuania, and the same trends of the EU countries (Belgium, Czech Republic, Denmark, France, Germany, Latvia, Lithuania, The Netherlands, Poland, Slovakia, and Spain) (European Environment Agency 2007). It can be stated that Lithuania and other European countries meet the increasing demand for build-up areas and traffic infrastructure. Lithuania, however, cannot explain the growth of the demand for land and traffic infrastructure, experiencing a noticeable decrease in population. Certainly, present results are gained within the macro level, they show the necessity of deeper elaboration, but the fact is that decisions to expand cities into green field areas shall be strongly based on demographic trends.

After regaining the Independence the main driving force of the growth has become a private housing sector (Fig. 4). From the point of sustainability, this process was poorly organized: in the areas where developers have possibility to rent land from the government either in the outskirts of the cities, or in the summer garden areas, it was done by changing the rural land into the urban.

From the housing "bubble" in the year 2007 till now a lot of housing property built for business purposes is in the market. The main reason is that their volume is too big and they were built in inappropriate areas, especially in the rural areas. The change of rural land to urban is an active process, compared to that of the city planning it is easy and flexible. Such active processes are going on around the metropolitan cities Vilnius, Kaunas, Klaipeda 
(Fig. 5). There is no legal and financial "stick" for those who do not use valuable rural land for production. Their owners mostly think that the use of rural land only for construction purposes is efficient. It may be that this current sociocultural paradigm is one of the causes of a substantial decrease in the total number of cattle in Lithuania (at the beginning of the XXI century its level reached the post war one) In this process of urbanization people have lost contact with soil and the services it provides to sustain their life (Braimoh 2008). Urbanization, however, in addition to its welfare is an important driving force in different environmental trends. For this reason, a monitoring system of urbanization should be sufficiently strong. There is a variety of techniques and data sources for capturing, storing, managing, and distributing the data on urban/ rural actions. Spatial planning should be based on sufficient understanding of the situation and should guarantee that natural resources, especially land, are efficiently used, and social interactions are provided with the necessary space.
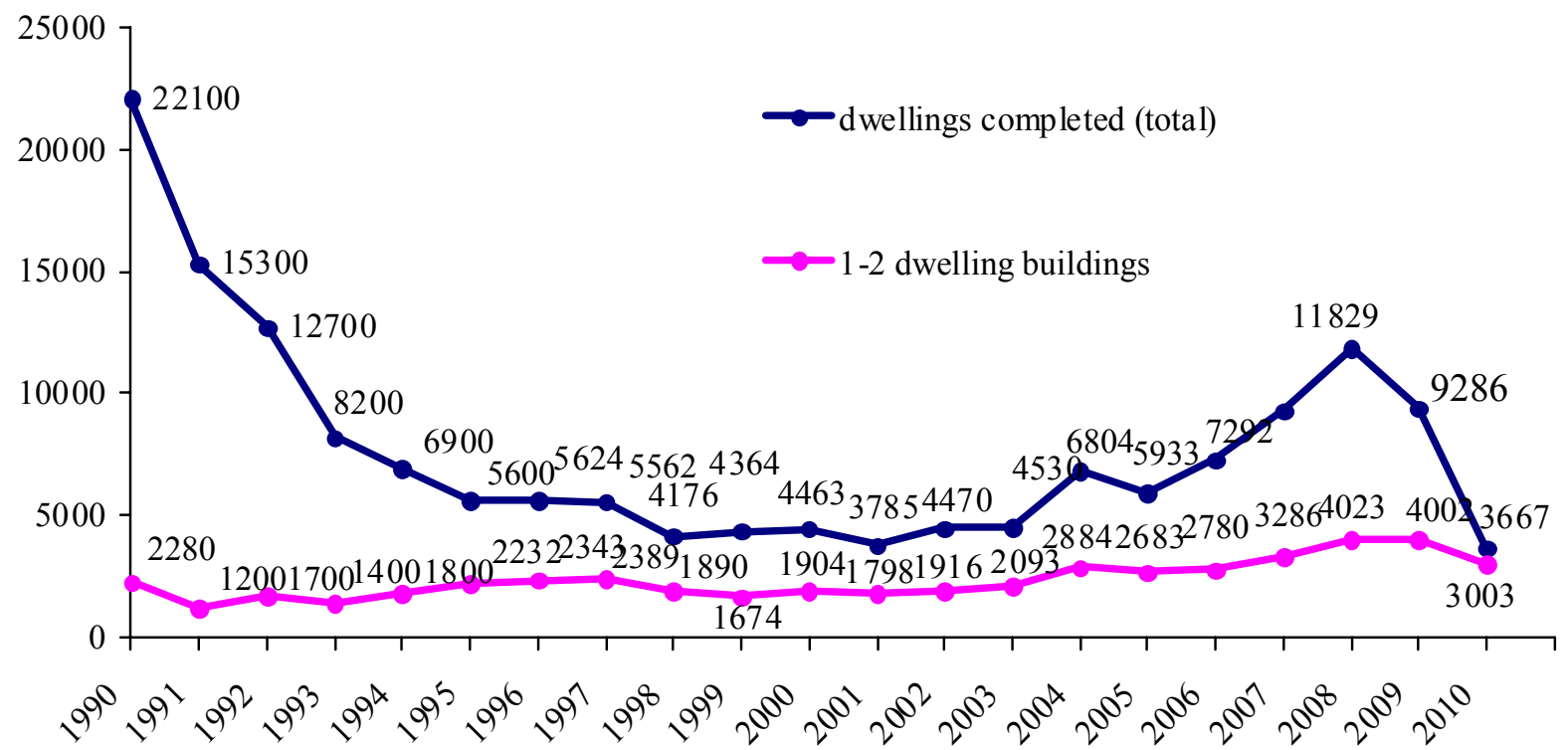

Fig. 4. The growth of housing sector in Lithuania (1990 - 2010)

\section{Master planning}

Lithuania inherited compact cities and landscape diversity after 1990. To the year 2009 not all municipalities had Master plans. The development was performed by detailed plans, where citizens or investors had their parcels and their own vision. Due to the prolonged restitution and privatization process, the city territories, that were planned to be developed with multistorey buildings, had shown high land prices, burdens on the infrastructure. It has brought a lot of Greenfield investments to the suburban areas. Suburbanization was also foreseen in the Master plans of municipalities, insufficiently motivated by developers to enhance the local economy. The urban sprawl is seen to be more of state or public not of individual interest. A house in the countryside is still Lithuanian's ideal. People are happy living in the surroundings of the natural landscape. Today rural areas around the biggest Lithuanian cities are occupied with worthless "suburban landscape", without any urban infrastructure, public spaces and with depredated relief, forest, hydrological systems, etc.

Looking for the reasons of the urban sprawl in Lithuania, the demand for new territories was analyzed in the Master plans of city and rural municipalities of Vilnius, Kaunas, Klaipeda alongside their compliance with demographic and housing estate trends, also with their relation with the costs of the housing property. Analytically calculated territories, intended for the new development are already urbanized in Master plans of Vilnius, Kaunas and suburban municipalities. Examples of the Master plan drawings are shown in Figure 6.

\section{Master planning}

Lithuania inherited compact cities and landscape diversity after 1990. To the year 2009 not all municipalities had Master plans. The development was performed by detailed plans, where citizens or investors had their parcels and their own vision. Due to the prolonged restitution and privatization process, the city territories, that were planned to be developed with multistorey buildings, had shown high land prices, burdens on the infrastructure. It has brought a lot of Greenfield investments to the suburban areas. Suburbanization was also foreseen in the Master plans of municipalities, insufficiently motivated by developers to enhance the local economy. The urban sprawl is seen to be more of state or public not of individual interest. A house in the countryside is still Lithuanian's ideal. People are happy living in the surroundings of the natural landscape. Today rural 
areas around the biggest Lithuanian cities are occupied with worthless "suburban landscape", without any urban infrastructure, public spaces and with depredated relief, forest, hydrological systems, etc.

Looking for the reasons of the urban sprawl in Lithuania, the demand for new territories was analyzed in the Master plans of city and rural municipalities of Vilnius, Kaunas, Klaipeda alongside their compliance with demographic and housing estate trends, also with their relation with the costs of the housing property. Analytically calculated territories, intended for the new development are already urbanized in Master plans of Vilnius, Kaunas and suburban municipalities. Examples of the Master plan drawings are shown in Figure 6.
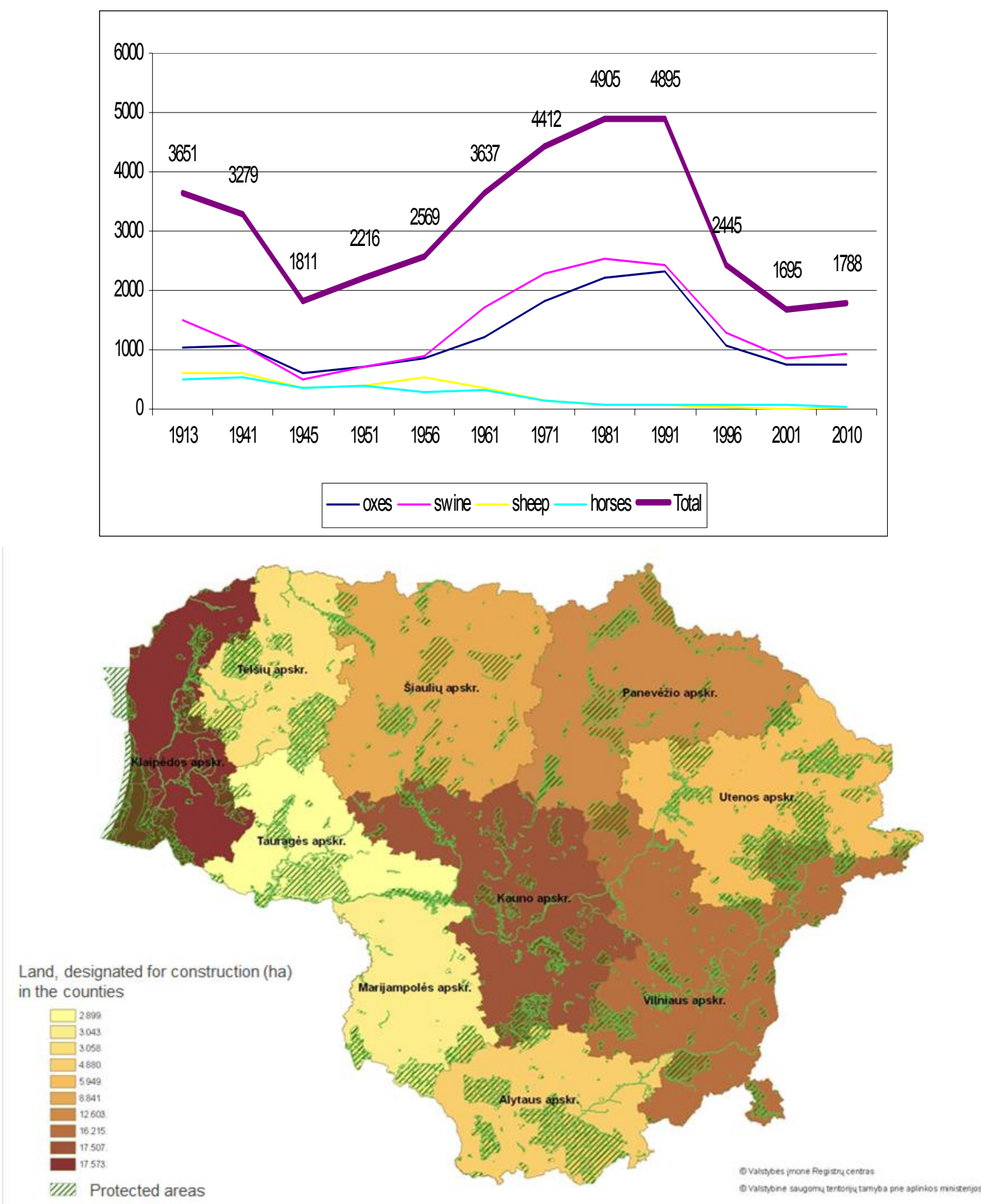

Fig. 5. Trends of land use change from rural towards urban and cattle-raising in Lithuania, XX-XXI century (source: The data from the SE 'Register center", 2011; Department of Lithuanian' statistic, 2010) 

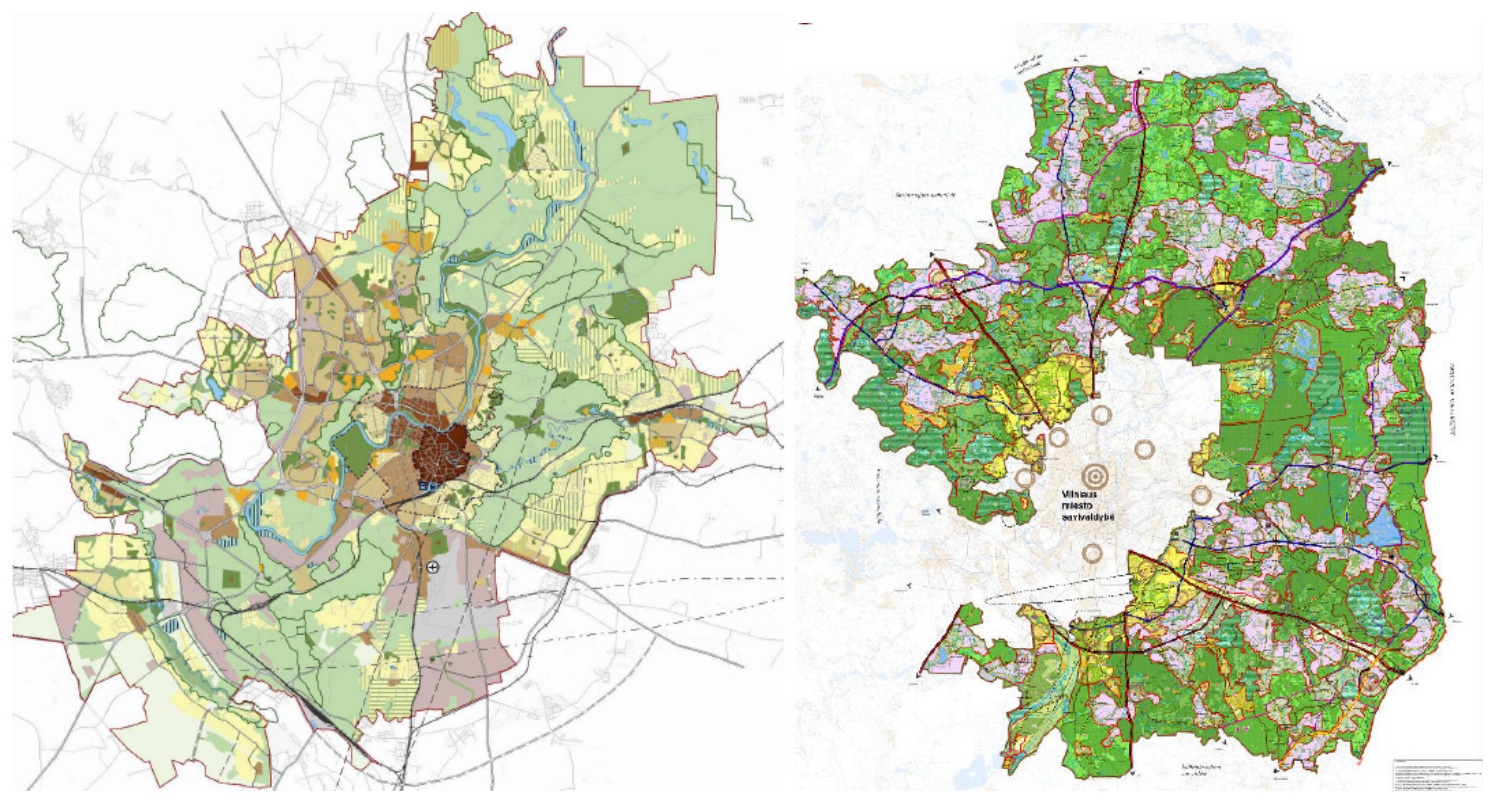

Fig. 6. Master plans of Vilnius and Vilnius region (sources: Master plan of Vilnius 2005 (left); Master plan of Vilnius region (right 2009)

When applying the population density, typical of European cities - 1 ha/30 inhabitants, it is true to say that Vilnius can settle twice as many people as it has now, in Vilnius region the number of people can be quadruplicated, Kaunas can be 1.4 times bigger, Kaunas region -2.5 times. Such hopeful plans do not indicate that demographical reality is under permanent changes process. Nevertheless, it is not an easy task to reject the foreseen "hyper - development", largely because of the landowners who think that it is a "legal expectation". Moreover, intention to use the land for construction is being considered as the perfect investment in comparison with the agricultural use. This shows the insufficient investigation into the demographic trend, performed by developers, who just "draw the settlements", gratify expectations of municipality authorities and citizens to have as many territories as they want for their bare land investment. That is why the cities are surrounded by chaotic urban structures (urban sprawl) and poor landscapes (Figs 78.).

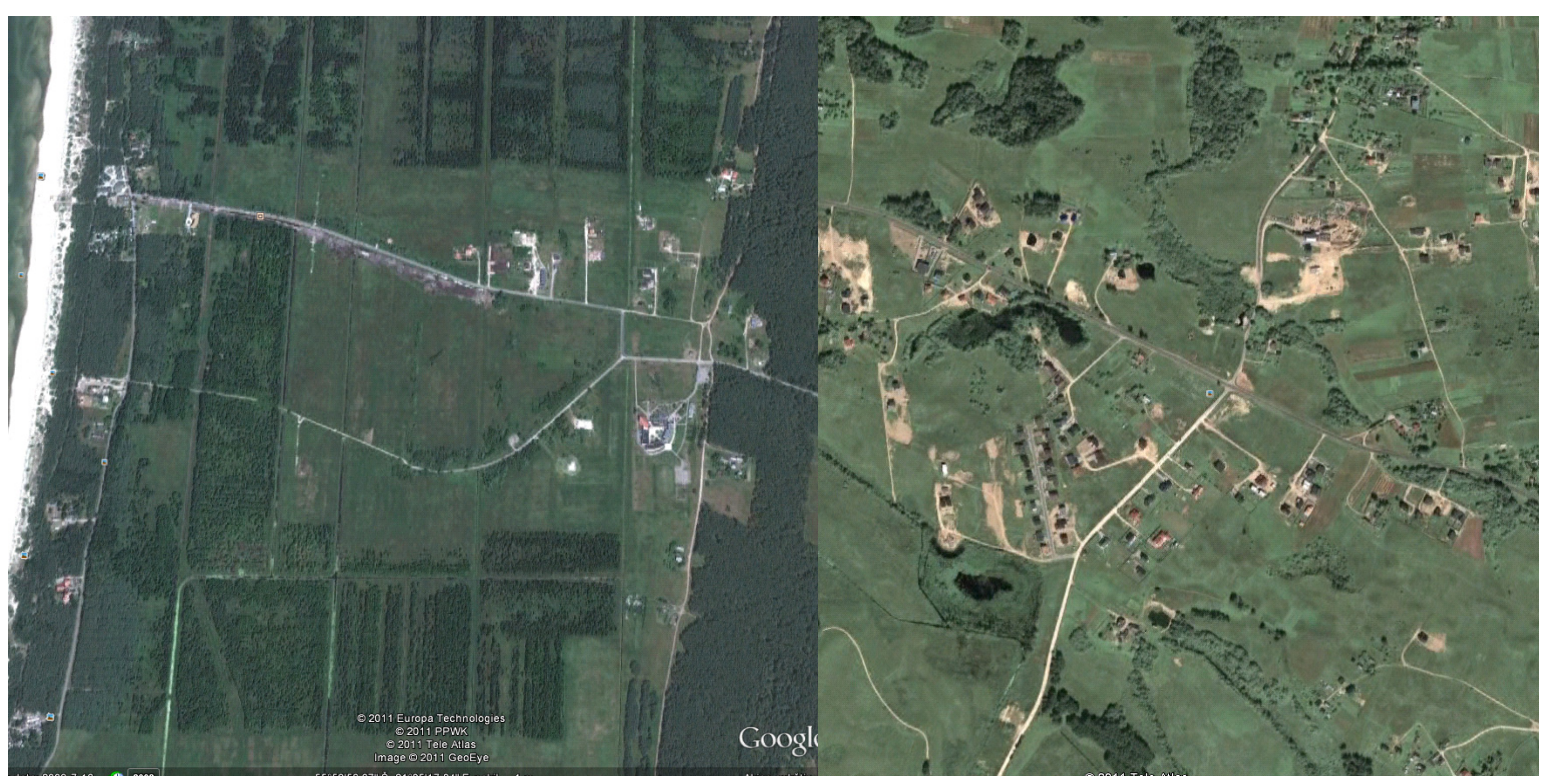

Fig. 7.

Chaotic urban formations near Klaipeda (on the left) and near Vilnius (on the right) are developed according to the "spot"master plans (source: Google 2011) 

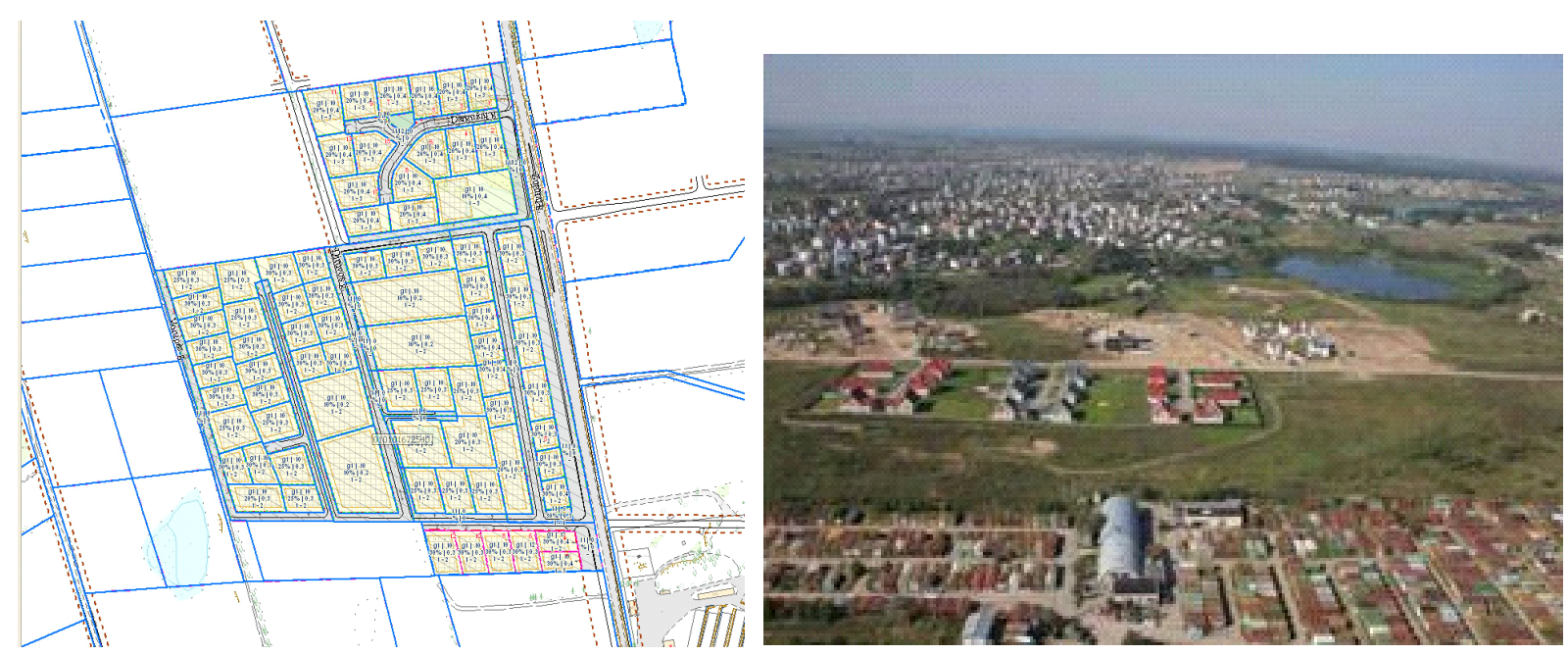

Fig. 8. Photo of an urban aesthetic view (left). An example of the "spot" detailed plan in the outskirts of Vilnius city without satisfactory infrastructure (right)
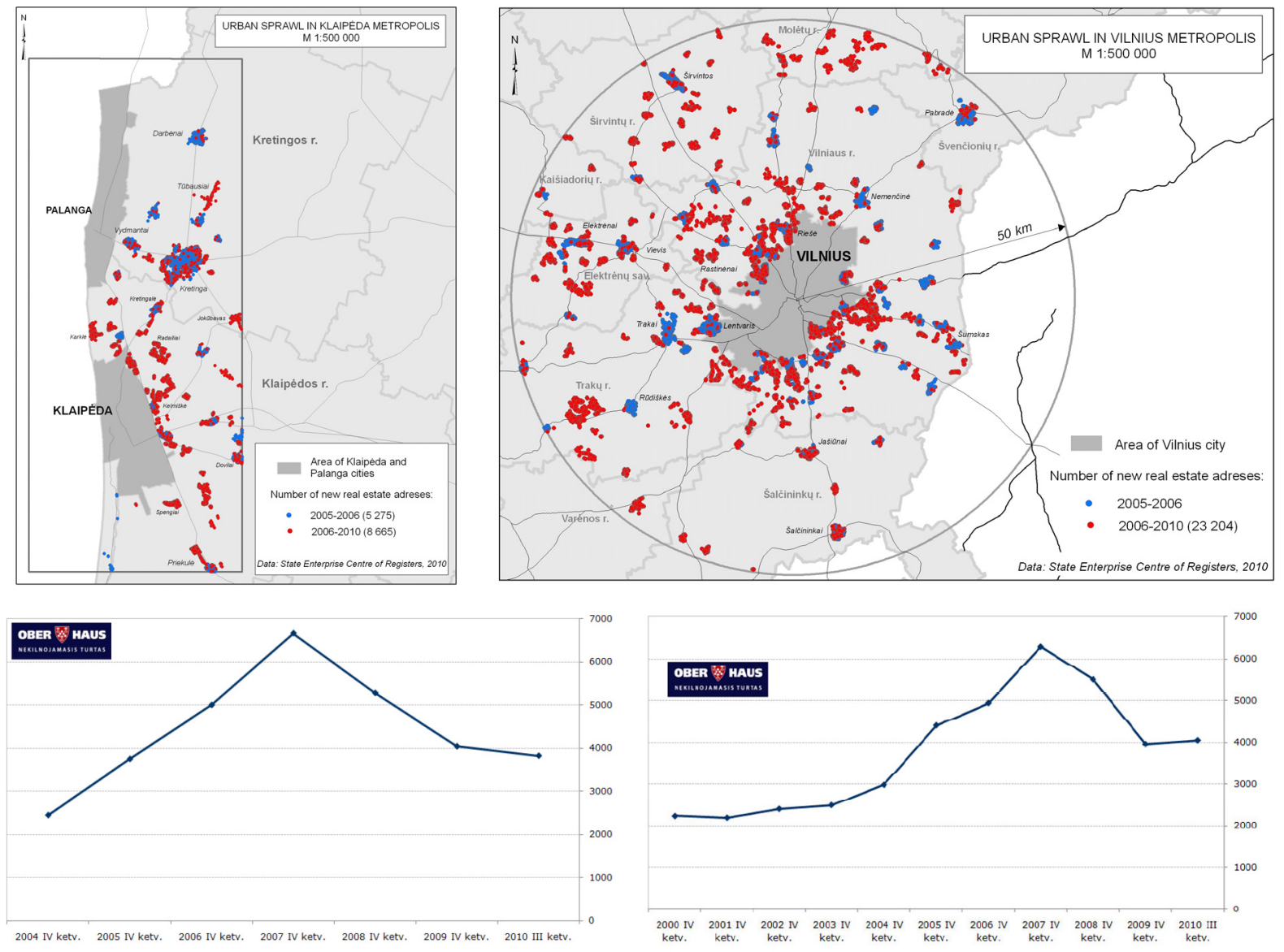

Fig. 9. Urban growth in Klaipeda (on the left) and in Vilnius (on the right) metropolitans and accommodation prices in Klaipeda and Vilnius (source: SE Register center 2010; source: Ober house) 
Klaipeda suburbs show active distribution of separate households and new settlements. Construction of one family houses in Klaipeda suburbs was related to the estate property "bubble" and to the will of citizens to have a "second home" near the Baltic Sea. Near Vilnius there are separate households that are already interconnected and form the "road settlements" without the public infrastructure, as it happens in the USA. Urban sprawl is induced by the following pragmatic factors: high costs of the land and accommodation in cities, low costs of the land and accommodation in rural areas, a prevailing trend of choosing a house with a yard and to live within natural surroundings. The trend is supported by the opportunity to get a mortgage for a second, or even the third house. The maps of Vilnius and Klaipeda registers of households in the suburbs and housing cost variations in Vilnius and Klaipeda were analyzed while looking for pragmatic reasons of the urban sprawl (Figure 9).

It could be stated that the main driver of the urban sprawl in Lithuania is the housing property "bubble" which appeared in 2006 - 2008 (Kaklauskas 2009). Analysis of the distribution of households among the suburban areas and housing prices in the cities shows that in Vilnius and Klaipeda regions, in 2006-2008 more households were built than it was done by the year 2006, when the overbalance between the city and the suburb was not as obvious as it is now (Figure 7).

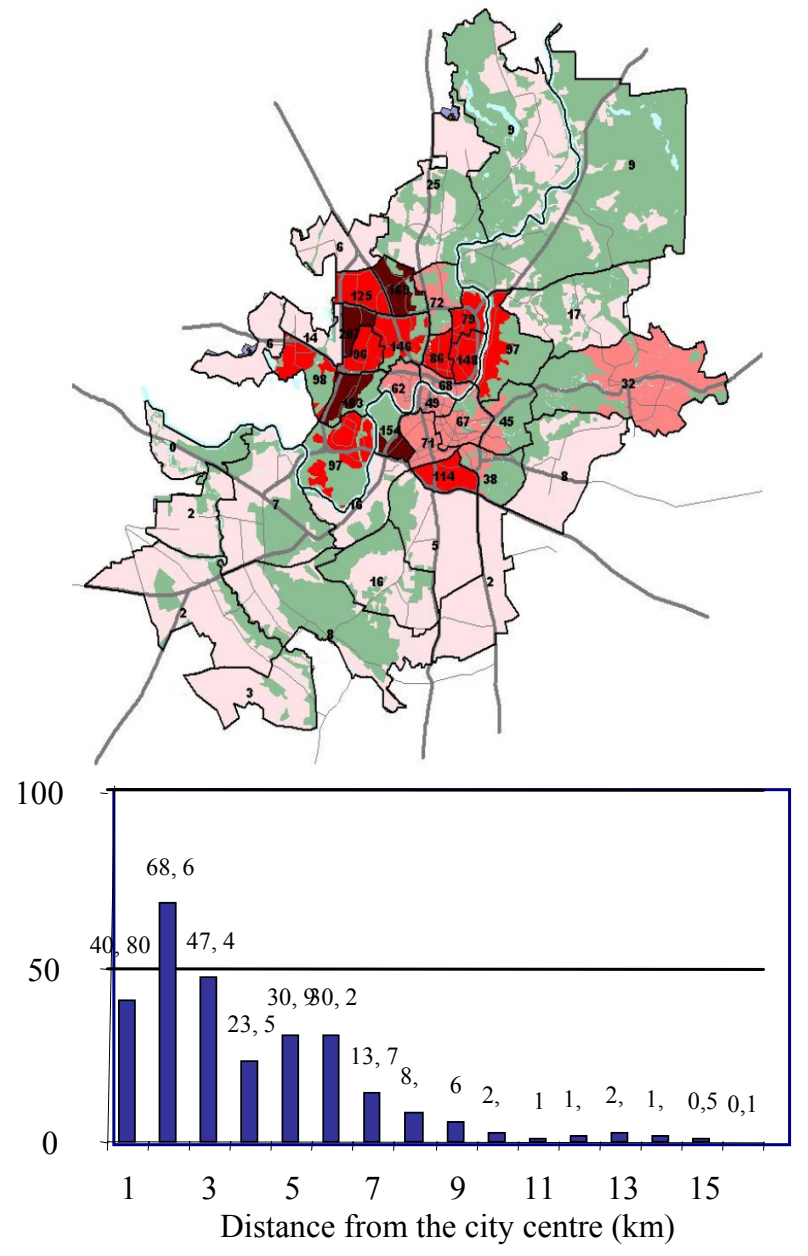

Fig. 10. Population density per hectare in Vilnius city (source: Master plan of Vilnius city 2005

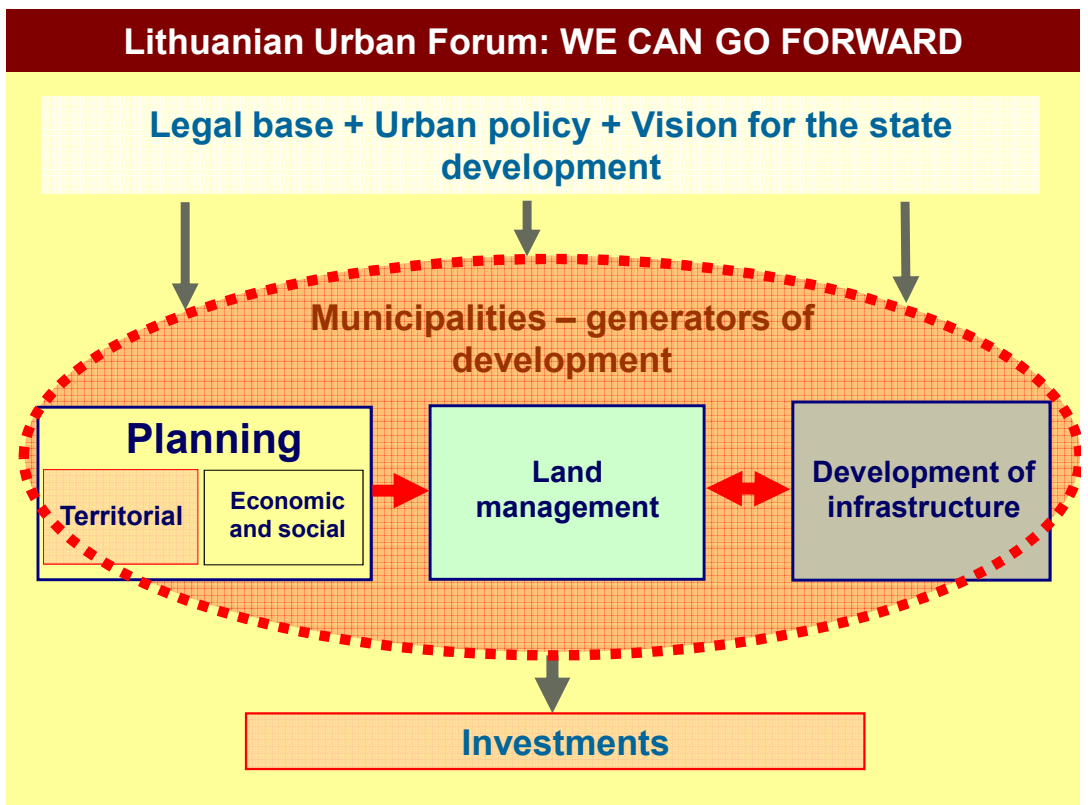

Fig. 11. The recommendations of Lithuanian Urban Forum (We can go forward) 
All over the world the population densities in cities differ: low densities (American) - with obvious centers and extensive suburbs up to 25 inhabitants/ha; high densities (Asian) - more than 150 inhabitants/ha; and European (balanced) - 30-100 inhabitants/ha. Densities of Lithuanian cities are comparatively low, for example, 48 inhabitants/ha live in Vilnius city, but, moving from the center to the suburbs it can be noticed that by the sixth kilometer the density reaches less than 30 inhabitants/ha and that brings increased transport costs and overspent energy (Fig. 10). The low density is identity and aesthetic feature of green Vilnius, but, on the other hand, it has its price. For example, the transport in Vilnius consumes 20,6 $\mathrm{GJ} /$ inhabitant. Comparing the energy consumption in transport with other cities of the world it shall be noticed that Vilnius is getting closer and closer to the cities which are oriented to the cheap fuel and individual transport and do not possess historical places isolated from transport and public areas that is a distinctive feature of Europe.

\section{Conclusions}

1. Urban sprawl is an acute issue in Lithuania, likewise in Eastern and Central Europe. The driving force of the sprawl in Lithuania is construction of the housing (too many buildings in unsatisfactory areas, especially in the rural areas). The change of rural land to the urban one is an active process going on around the metropolitan cities. Since urbanization of the rural land continues, people are prone to loose their contact with soil and services it provides to sustain their life. The analyses of the current urban trends (demographic, land use, housing energy use, private cars, etc. ) and the Master plans of Lithuanian cities and their neighboring municipalities show the need of realistic, foresighted urban planning and coordinated urban/rural policy.

All generations are responsible for a spatial future of the cities, their compactiveness. Responsibility should be based on clear understanding of the existing situation, its vision and its politics, implemented by strategic master plans, made by learned professionals. The guide of urban development without sprawl can serve the EU policy, global urban professional organizations and famous urban thinkers of the world.

2. In Lithuania the National Urban Forum movement from 2007 till now is playing a mutual role in formulating and implementing sustainable urban/rural policy. The recommendations of the Forum for improving the existing territorial planning situation are shown in Figure 11. It presents at the state level the following measures: the new territorial planning law which at the moment is under discussion at the Parliament of Lithuania, coordinated urban/rural policy, spatial vision for the state landscape At the local level: integrated spatial social and economical planning; effective land management; sufficient infrastructure development. The investments should be on the line of state and local government decisions and support. It will give stability and sustainability for the investors. The measures indicated above could help to stop "pumping up vital forces" from cities to rural areas, to stop increasing the need and costs of infrastructure and polluting the environment, to provide the use of the existing urban areas (brown field versus green field investment). The existing IT technologies and databases can help in monitoring the urban growth and providing adequate strategies.

3. To implement the recommendations and tasks shown in Figure 11 is practically possible through learning and adopting the best practices of the EU countries (notably in Northern Europe) which have strong planning systems able to achieve the sustained growth without sprawl.

Being the members of the Lithuanian Urban Forum, the authors state that these measures will be of assistance in obtaining the territorial planning foresighted in solving the current urban development tasks raised for Lithuanian cities. They will make it possible to manage and use the land potential effectively in the inner territories of the city, they will improve the existing public infrastructure and will stop the urban sprawl and the growth of energy consumption and environment pollution.

\section{References}

Bardauskienè, D., Pakalnis, M. 2011. The impact of urban trends on the renovation of the center of city. Town planning and architecture, Nr. 4:2011, p. 276-284.

Braimoh, A.K. and P.L.G. Vlek (2008). Land Use and Soil Resources. Springer. ISBN 978-1-4020-6777-8. http://dx.doi.org/10.1007/978-1-4020-6778-5

Chris Couch, Lila Leontidou, Gerhard Petschel-Held. „Urban sprawl in Europe: Landscapes, Land-use change @ polisy“. Bleackwell Publishing: 2007.

European Environment Agency. "Urban sprawl in Europe, the ingnored challenge". Report: No 10/2006.

EU Council of Ministers for Urban Development and Territorial Cohesion (UTDC), (2007b). "The Leipzig Charter on Sustainable European Cities". http://www.eu2007.de/en/News/download_docs/Mai/0524AN/075DokumentLeipzigCharta.pdf, last accessed October 19, 2007.

European Union (EU, 2006). Review of the EU Sustainbale Development strategy (EU SDS) Renewed strategy, The Council of the European Union, 10117/06.

ISOCARP Review 04. "Urban Growth without Sprawl". International Society of City and Regional Planners, 2008.

Fourth Lithuanian Urban Forum "Urban sprawl: clash of urban and rural". Kaunas Technology university: 2010.

Kaklauskas, A., Bardauskiene, D. "City and housing development sociocultural aspects". Third Lithuanian Urban forum issue, Vilnius: 2009, p. 27-29; 
Assoc. Prof. Dr. Dalia Bardauskienè in Vilnius Gediminas Technical University, Economy and Real Estate Development department.

Main research area: Sociocultural aspects of sustainable city development.

Address: Vilnius, Padekaniškių 8-21

Tel.: $\quad+37061123712$

E-mail: dalia.bardauskiene@Intpa.lt
Assoc. Prof. Mindaugas Pakalnis in Vilnius

Gediminas Technical University, the faculty of Architechture.

Main research area: urban planning methodologies and practices.

Address: $\quad$ Vilnius, Sauletekio 11

Tel.: $\quad+37068887128$

E-mail: mindaugas.pakalnis@v.planas.lt 